REFLECTIONS:

NEUROLOGY AND

THE HUMANITIES

Section Editor

Anne W. McCammon,

MD, FAAN

\title{
Charades with Alzheimer disease
}

Rebecca Grossman-Kahn, BA

Correspondence to R. Grossman-Kahn: rcgk@med.umich.edu
In 2008, I took my first office job after college, which happened to be a few blocks away from the Alzheimer disease residential care unit my grandmother had just moved into. When I arrived to visit her on my lunch break, she paced the hallways of the nursing home, looking for my grandfather. She was like a bird: fidgety and flighty, the slight curve of her nose accentuated by the weight she had lost. Her red sweaters were too big for her now, and her favorite hat was a gray newsboy cap that belonged to my grandpa. When he finally arrived to visit, she would throw her arms around his neck and kiss him.

They sat together in 2 armchairs, holding hands. My grandpa is short, bald, and very round. He wore brown slacks buckled below his breastbone, and bright white and blue New Balances. My grandma wore an eclectic collection of necklaces, and one white glove. Her hair was brushed to the side and her face was as pale and dry as flour. "Doesn't she look lovely?" my grandpa asked me. "Yesterday I came when she was sleeping and she looked angelic. Just ... angelic."

"Angelic" is not the first word people who knew my grandma would have used to describe her. Strongwilled, stubborn, outspoken, perhaps. She had a sharp tongue and held grudges. Most people would have described my grandma as feisty, determined, and indomitable. She had had a difficult childhood after being abandoned by her mother, and had always been suspicious of others. She met my grandpa at Bellevue Hospital when she was a 22-year-old nurse. In him, a soft-spoken, stalwart pediatrician with a thick Russian accent, she must have seen unwavering stability: someone who would never leave her. She could trust that his measured, pragmatic outlook would be a lifelong match for her exuberance.

Under the early spell of Alzheimer disease, my grandma's fiery spirit intensified, her suspicions increased. Sometimes she would get really angry at my grandpa. When he tried to help her comb her hair, she would clutch onto the brush. "Mine," she growled. She narrowed her eyes and peered suspiciously at anyone who tried to help her. Or worse, she might raise the brush in a threat. But my grandfather never lost his patience, or his perspective as a physician. She was sick, and the disease made her behave this way.

We took her out to eat at the neighborhood Mexican restaurant and ordered her enchiladas we knew she wouldn't finish. She poked at the floppy tortillas with her fork and bristled when we encouraged her to eat. Instead, she anxiously fixated on the bit of salsa or cheese my grandpa had on his lips. She furrowed her brow and swatted violently at the offending piece of food.

She went to bed at 6:30 PM and woke up and got dressed and came downstairs again at 9 PM, ready for breakfast. She paced the house, picked things up and hid them. She routinely tested my grandpa's patience as he answered the same questions many times in a row. To try to harness her energy, to get her to sit still, my grandpa told her it was time to "escape the fog." Then he'd take her on long drives out to the ocean or down the peninsula.

Even as she surrendered to the proteins aggregating in her brain, and there was an emptiness in her eyes so quickly concealed with a laugh, my grandpa always treated her the same, as if she did not have a disease. He did not miss a beat when she called his blue plaid pajamas a "nice lookin' suit" or asked if they had to fly to get the movies. He asked if she wanted grapefruit for breakfast every morning, even when she no longer recognized the word grapefruit.

I would later wonder how my grandfather kept up what looked, to me, like a charade. Why treat my grandma as if nothing had changed? Why did he continue to tell her the gossip from the neighborhood coffee shop? Didn't he realize she didn't understand anymore? Was it simply habit that led him to hand her the crossword puzzle every day? Was it his medical training or quiet personality that allowed him to appear so calm in the face of my grandmother's descent into Alzheimer disease? In his years as a physician, had he truly learned how not to grieve the onset of illness? My grandfather was famous for his intuitive bedside manner, and I liked to think his behavior was a deliberate doctor's trick he used to help my grandmother feel safe. At the same time, I couldn't help but wonder if his love for her had blinded him to just how much she had lost. Maybe 
he was not a clever doctor but a lovesick husband, in denial about my grandma's confusion.

She regularly fooled strangers into thinking nothing was wrong by picking up on subtle emotional cues and mirroring others' emotions. She spewed aphorisms that were vaguely appropriate. She was an excellent actress, whether she realized it or not, and her charisma carried her far. "I guess you just have to blow your nose. At times like this, it's the only other thing to do," she might say to fill a gap in conversation and make everyone laugh.

Suddenly, she was a poet.

"My sweater new? Not too new. A little smidgeypoo, if you know what I mean.

And my hair! It's a black bloom.

Oh, I'm a whirl, a whirl."

She occasionally displayed remarkable, heartbreaking clarity. "I think I'm losing my mind," she told me once. I kept track of her quotes in a small paperback notebook. Despite all she'd lost, I thought she really did gain a more beautiful way of seeing the world. She even thought pigeons were "adorable little fellas." I compulsively wrote it all down, to safeguard against my own forgetting, as if to offset my grandmother's disappearing memory.

As the disease wore on, it stripped the spines from her shell. In her final months, she never called my grandpa "turkey" or "devil" anymore; only "darling," and "my wonderful Misha." She started to greet me with "Hello, you look beautiful." The disease brought out the sweetness my grandfather must have always seen in her. Once, we took her out of the nursing home for lunch, and she asked my grandpa for a kiss - in the middle of eating, in the center of the café. When he kissed her she said "higher," and he knew she meant "harder." So he kissed her again. Firmly, squarely, on the lips, and then my grandpa smiled his gap-toothed smile. This was the first time I can remember seeing them kiss in public.

I continued to visit my grandma at the residential home throughout the rest of that year. She always wanted to hold hands, although she did not know who I was. I have never felt anything as soft as her hands. The skin was thin and cool, with the bluish tint of skim milk. There was a dark purple puddle of escaped blood in the flap of skin between her thumb and pointer finger. In her reclining chair she closed her eyes. Her mouth fell open and she began to snore. I wondered what her dreams were like. I imagined they transported her to a more whimsical world, where pajamas are formal wear, pigeons are cute, and everyone flies to the movies. Or perhaps, because being awake is confusing and dream-like enough, her dreams are logical, clichéd adventures. My grandfather is always the hero. 


\title{
Neurology
}

\author{
Charades with Alzheimer disease \\ Rebecca Grossman-Kahn \\ Neurology 2016;86;e73-e74 \\ DOI 10.1212/WNL.0000000000002402
}

This information is current as of February 22, 2016

Updated Information \&
Services

Subspecialty Collections

Permissions \& Licensing

Reprints including high resolution figures, can be found at: http://n.neurology.org/content/86/8/e73.full

This article, along with others on similar topics, appears in the following collection(s):

All Cognitive Disorders/Dementia

http://n.neurology.org/cgi/collection/all_cognitive_disorders_dementia Alzheimer's disease

http://n.neurology.org/cgi/collection/alzheimers_disease

Information about reproducing this article in parts (figures,tables) or in its entirety can be found online at:

http://www.neurology.org/about/about_the_journal\#permissions

Information about ordering reprints can be found online:

http://n.neurology.org/subscribers/advertise

Neurology ${ }^{\circledR}$ is the official journal of the American Academy of Neurology. Published continuously since 1951, it is now a weekly with 48 issues per year. Copyright (O 2016 American Academy of Neurology. All rights reserved. Print ISSN: 0028-3878. Online ISSN: 1526-632X.

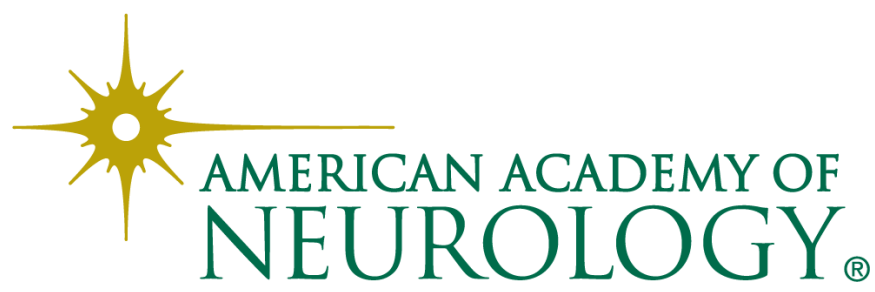

